\title{
Article
}

\section{Methodological challenges of transdisciplinary research}

\author{
Christian Pohl ${ }^{1}$, Gertrude Hirsch Hadorn ${ }^{2}$ \\ 1 Environmental sciences, transdisciplinary research, transdisciplinarity-net, Swiss Academies of Arts and Sciences, 3007 Bern, \\ and Department of Environmental Sciences, ETH Zurich, 8092 Zurich, Switzerland \\ 2 Environmental Philosophy, Institute for Environmental Decisions, ETH Zurich, 8092 Zurich, Switzerland
}

\begin{abstract}
Christian Pohl et Gertrude Hirsch Hadorn présentent dans cet article les bases conceptuelles et méthodologiques de la recherche transdisciplinaire telle qu'elle est développée et défendue dans le cadre du réseau $t d$-net qu'ils animent tous les deux pour les Académies suisses des sciences. C'est pour NSS l'occasion de s'ouvrir aux approches interdisciplinaires d'autres courants européens, ici celui de la "transdisciplinarité". Nous publierons, dans le prochain numéro, une réaction à cet article de la part de Ray Ison, Professeur de Sciences des Systems à l'Open University (Milton-Keynes, UK)... en attendant celles d'autres lecteurs.
\end{abstract}

La Rédaction

\section{Keywords:}

methodology of transdisciplinary research;

forms of knowledge; transdisciplinary research process; means of integration; specialization in transdisciplinary research

\section{Mots-clés :}

méthodologie de la recherche transdisciplinaire ; formes de savoir ; processus de recherche transdisciplinaire; moyens d'intégration; spécialisation en recherche transdisciplinaire

\begin{abstract}
Transdisciplinary research (TR) develops descriptive, normative and practice-oriented knowledge in order to help solve, mitigate or prevent life-world problems. TR deals with problem fields in such a way that it can (a) grasp the complexity of problems, (b) take into account the diversity of scientific and life-world perceptions of problems, (c) link abstract and case-specific knowledge, and (d) develop knowledge and practices that promote what is perceived to be the common good. For these purposes disciplinary researchers and actors of the life-world collaborate. They contribute substantial knowledge about the issue (practical experience, scientific models, results) as well as formal approaches (methods from systems dynamics, operational or action research, etc.). These knowledge bases have to be interrelated and transformed through the specific problem field during the research process: in problem identification and structuring, in problem analysis as well as in bringing results to fruition. We discuss the interrelation of knowledge bases in relation to requirements a-d. Furthermore, we identify particular transdisciplinary challenges and propose methods and tools to address them.
\end{abstract}

Résumé - Le défi méthodologique de la recherche transdisciplinaire. La recherche transdisciplinaire (RT) développe des savoirs descriptifs, normatifs et orientés vers la pratique pour aider à résoudre, atténuer et prévenir des problèmes du monde vivant. La RT aborde les problématiques d'une manière qui lui permet de (a) saisir la complexité des problèmes, (b) prendre en compte les perceptions diverses des problèmes, selon qu'elles émanent de la science ou du monde vivant, (c) établir des liens entre savoirs abstraits et spécifiques à des cas concrets, et (d) développer des savoirs et des pratiques qui promeuvent ce qui est perçu comme étant le bien commun. Des chercheurs disciplinaires et des gens de la pratique collaborent à ces objectifs. Ils fournissent un savoir substantiel sur la question abordée (expérience pratique, modèles scientifiques, résultats) ainsi que des approches formelles (méthodes de dynamique des systèmes, recherche opérationnelle ou recherche-action). Pendant le processus de recherche, ces bases de connaissances sont reliées entre elles et transformées par leur mise en œuvre dans une problématique spécifique : lors de l'identification et structuration des problèmes, lors de l'analyse de ces derniers de même que lors de la mise en valeur des résultats. Nous discutons l'interrelation de bases de savoirs en rapport avec les objectifs a-d. En outre, nous identifions des défis transdisciplinaires spécifiques et proposons des méthodes et des outils pour les aborder.

\section{Introduction}

What if a scholar who becomes interested in transdisciplinary research (TR) asks you: what are the methods that

Corresponding author: C. Pohl, pohl@scnat.ch you use? What concepts and theories is your research based on? And what skills do I have to develop to become a transdisciplinary researcher? What do we answer this scholar? Do we give "the top recommendation for students [...] to cross boundaries between disciplines 
and to take a broad range of courses while developing a solid background in one discipline"(Klein, 2008, 403)? Is competence in TR developed in a personal dispute on alternative disciplinary approaches, based on a strong background in a home discipline? Or will the answer be that a new specialisation in science is under way around the three pillars of systems thinking and complexity science, participatory methods and knowledge management (Bammer, 2005), and that the scholar should better study those theories and methods?

The present literature on TR does not propose a coherent theory and methodology of TR. Yet it identifies a number of relevant skills that a researcher in TR should bring along (Hollaender et al., 2008, 388; Klein, 2008, 406): social and communication skills are needed for the exchange between disciplinary researchers and actors of the life-world; cognitive skills are required in order to "integrate knowledge stocks of different action domains (both within academia and between researcher and other societal actors) and to develop solutions that respond to the expectations of different actors groups" (Truffer et al., $2003,108)$. What the cognitive skills should facilitate is also referred to as synthesis.

In what follows we describe the methodological challenges of TR, based on the understanding of TR and of the transdisciplinary research process that we developed within td-net (see Box) during the last years. We discuss how theories, methods and insights of specific disciplines or research fields may feed into and be transformed during a transdisciplinary research process. Furthermore, we identify particular transdisciplinary challenges and propose methods and tools to address them. We conclude by briefly discussing how far the methodological challenges support the idea of a formalized specialisation in TR (Kueffer et al., 2007).

\section{Transdisciplinary research}

We conceive of TR as a research activity that suits specific types of life-world problems. The starting point for TR is a socially relevant problem field. A problem field (e.g., violence, hunger, poverty, disease, environmental pollution) refers to an issue in the life-world. Problem fields are socially relevant when those involved have a major stake in the issue, when there is a societal interest in improving the situation and when the issue is under dispute. Those involved may agree neither on the relevance of the problem, nor on its causes, nor on the solution strategy required. TR provides knowledge for such kinds of situations. When pursuing this goal and identifying, structuring, analysing and dealing with concrete problems in a problem field, it is necessary to consider four fundamental requirements. "TR deals with problem fields

\section{Box 1. Transdisciplinarity-net}

Transdisciplinarity-net (td-net, www.transdisciplinarity.ch) was initiated 2003 by the Swiss Academies of Arts and Sciences. It includes a scientific advisory board and a science office. The long-term ambition of td-net is to support transdisciplinary research in becoming a form of research with its own standards in problem fields such as migration, emerging technologies, public health or global change. td-net supports transdisciplinary research by facilitating mutual learning between problem fields, by providing basic material and by facilitating community building. td-net's main publications are the Principles for Designing Transdisciplinary Research: Proposed by the Swiss Academies of Arts and Sciences (Pohl and Hirsch Hadorn, 2007) and the Handbook of Transdisciplinary Research ${ }^{a}$ (Hirsch Hadorn et al., 2008). td-net contributes to two priority areas of the Swiss Academies of Arts and Sciences: foresight and the dialogue between science and society.

G. Hirsch Hadorn is president of td-net, C. Pohl is co-chief science officer.

a See in this issue, heading Lecture - Sélection thématique, the presentation of this book.

in such a way that it can:

(a) grasp the complexity of problems,

(b) take into account the diversity of life-world and scientific perceptions of problems,

(c) link abstract and case-specific knowledge, and

(d) develop knowledge and practices that promote what is perceived to be the common good." (Pohl and Hirsch Hadorn, 2007, 20.)

We define TR by these four requirements for knowledge production, which arise as a result of TR's goal to provide descriptive, normative and practice-oriented knowledge. The inclusion of actors of the life-world into the research process and the collaboration of researchers in order to transcend and integrate disciplinary paradigms are means to fulfil the four requirements. Who could or should contribute in TR has to be considered when structuring a research project.

By seeing the inclusion of actors of the life-world and the collaboration of researchers as means to meet the four requirements, we propose a goal-oriented definition of transdisciplinary research. This is an alternative to definitions that see either the inclusion of actors from the private sector, public agencies or the civil society into the research process (Defila and Di Giulio, 1999; Lawrence, 2004) or the transcendence and integration of disciplinary paradigms (Jantsch, 1972; Mittelstraß, 1996) as the attribute that distinguishes transdisciplinarity from other forms of research.

Our understanding of TR is based on a survey of definitions and refers, as a synthesis work, to several elements of other definitions (Pohl and Hirsch Hadorn, 2007, 70-95). The starting point of TR, which is characterized 
by uncertainty about the situation and high stakes for those concerned, refers to Funtowicz' and Ravetz' description of post-normal science (Funtowicz and Ravetz, 1993). The requirement to grasp the complexity of a problem can be related to Erich Jantsch's definition of transdisciplinarity, inspired by systems theory thinking (Jantsch, 1972, 105-106). The requirement to take into account the diversity of perceptions is expressed in the call for participatory research (Häberli and Grossenbacher-Mansuy, 1998; Defila and Di Giulio, 1999) as well as for collaborating disciplines (Mittelstraß, 1992; Costanza, 2003). The requirement to interrelate abstract science and case specific knowledge derives from the field of intervention research (van den Daele and Krohn, 1998; Argyris and Schön, 1999; Hubert and Bonnemaire, 2000; Groß and Hoffmann-Riem, 2005). The orientation to the common interest finally is implicit to definitions that adjust knowledge production to problems of life-world - rather than disciplinary boundaries (Mittelstraß, 1992). This orientation to the common interest is rarely stated explicitly in definitions of transdisciplinarity, contrary to the field of policy sciences (Clark, 2002,13) or technology assessment (Grunwald, 1999, 243). It is one of the tasks of the transdisciplinary research process to clarify the concept of common interest for the context of the project.

Figure 1 describes the structure of a transdisciplinary research project as a system. The elements of the system are: the problem field, researchers from particular disciplines and actors of governmental and other public institutions, the private sector, the civil society or another sector of society. The term "system" refers to the interaction of these elements during the research process, i.e., by discussing what the problem is about, by investigating the problem, by deliberating about values and goals, or by developing measures. The reason why they interact is the shared aim to improve a particular situation in a problem field of the life-world, hunger in this case. The actors of the life-world and disciplinary researchers are interrelated via this shared concern. This is the reason for expressions like "problem-solving" (Clark, 1999, 393) or "issue-driven" research (Robinson, 2008).

The transdisciplinary research process consists of three phases: problem identification and structuring; problem analysis; bringing results to fruition (Pohl and Hirsch Hadorn, 2007, 42-43). The systems structure of a transdisciplinary project is involved in all three phases. The elements and their relations provide the basis for identifying the problem, to analyse underlying mechanisms, to develop and propose measures and for testing the measures in order to learn whether they have the potential to change the problem situation as intended. The intensity of involvement of specific scientific and lifeworld perspectives - whether the project team can refer to existing knowledge or whether knowledge is missing so that certain actors and researchers have to become part

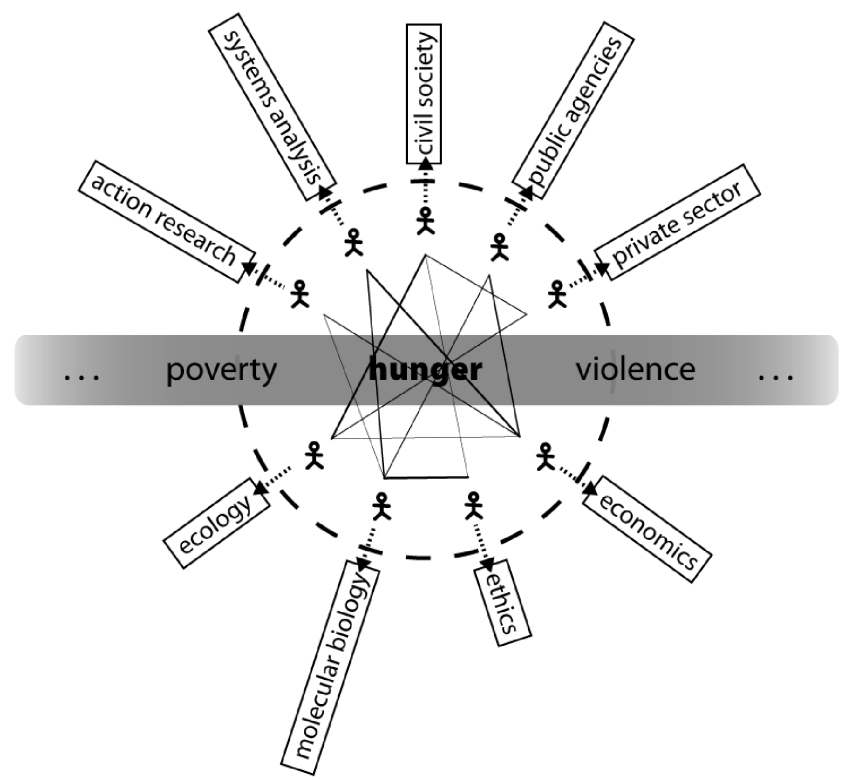

Fig. 1. In transdisciplinary research, scientific disciplines (represented by individual researchers) and sectors of the life-world (represented by individual actors) are getting interrelated and transformed through a problem field. A transdisciplinary research project is the system build by the collaborative research process.

of the project team and play an active role in providing knowledge - has to be decided by relating to the four requirements of TR.

\section{Methodological challenges}

As depicted in Figure 1 each of the participants in a TR project has a specific home base either in a discipline/research field or in a practice field. The knowledge that participants can provide from their home base includes substantial knowledge about the issue such as practical experience in the case of stakeholders and practitioners, or, in the case of researchers, scientific models and results about the issue as well as formal approaches, such as methods from systems dynamics or action research. These various knowledge bases have to be interrelated through the specific problem field, hunger for example. In the following we discuss the interrelation of knowledge bases in relation to the four requirements of TR. For each requirement we discuss the transdisciplinary challenges of disciplinary contributions and their transformations that feed into a transdisciplinary research process.

\section{Complexity of problems}

In TR a problem of the life-world is framed as a node in a web of heterogeneous factors. Taking into account the complexity of a problem means addressing interrelations 
among the social, natural, technical, legal, etc. factors that constitute the problem and might influence the impact and acceptance of proposed solutions. The situation is complicated, since interactions among factors may change over time. So, ideally, the dynamic interdependencies of a range of empirical insights, value orientations and policy options (such as technologies, economic incentives and regulations) are captured.

The transdisciplinary challenge with complexity of problems is that of interrelating the broad range of factors to come up with an integrated understanding of the problem and integrated suggestions for dealing with the problem. Therefore Jantsch (1972) and scholars after him (e.g. Bammer, 2005; Robinson, 2008) consider systems thinking, whether hard or soft, to be a constituting conceptual basis of the transdisciplinary research perspective. As far as systems theory (see Midgley (2003) for an overview) is considered to be a discipline - namely in the sense of a formal discipline that can be applied to a wide range of problems - systems thinking is a disciplinary contribution to the transdisciplinary challenge of integration. The term "system" basically means that the emphasis of an analysis shifts from the elements to the way they interact (Jantsch, 1972 , 103). To focus on interrelations means to adopt systems thinking. Meadows et al. (1972) introduced systems thinking to environmental or sustainability research through the world model. They modelled the development of the world as interactions between resource usage, population growth, pollution, and economic and agricultural growth. Checkland (1994) supplemented this hard systems thinking with soft systems thinking. Both differ in the way they qualify the model's relation to the life-world: in hard systems thinking the models are models of the world; in the soft systems thinking the models are "models which embody a particular stated way of viewing the world" (Checkland, 1985, 764). As a consequence, the challenges of integrating perspectives in soft systems thinking are different from the challenges of integrating findings from different disciplines in a model of the world.

In hard systems thinking, disciplines may contribute knowledge on parameters that play a role in the issue and help get an enhanced model of the problem in the sense of how various parameters are correlated. While an economist can provide data on economic variables as reasons for hunger, molecular biologists can study the problem on the level of nutrients and ecologists on the level of the dynamics of global environmental change. Their results can be integrated in a qualitative or quantitative model.

Soft systems thinking takes the fact into account that scientific findings are meaningful only in relation to the conceptual and methodological framework of a discipline. On that condition what needs to be done is not e.g. to integrate data, but disciplinary perspectives.
Furthermore integration of scientific perspectives has to be complemented by the perspectives of actors in the life-world, which are framed by their specific roles and experiences. Wynne gives an example of how both - general scientific knowledge and contextualized knowledge of stakeholders - are needed for an effective problem handling in the case of Tschernobyl fallout and farmers and their grazing sheep around Sellafield (Wynne, 1992). The Bagamoyo College of Arts (2002) shows how effective AIDS/HIV prevention in the districts of Kisarawe, Musoma, Nasasi and Bagamoyo in Tanzania has to rely on - besides medical knowledge - a sound understanding and an open discussion of the sexual habits within the high risk group of young people, an issue that is traditionally taboo. Accordingly, Agenda 21 states in the chapter on science for sustainable development (Chap. 35.5) that "[s] ustainable development requires [...] using the best scientific and traditional knowledge available." Therefore, diversity of perspectives, the second requirement for TR, is among the major challenges in addressing the complexity of a problem.

\section{Diversity of perspectives}

Researchers as well as actors in the life-world perceive a problem and the factors that cause it as well as its consequences in various different ways. Together, they represent a diversity of perceptions or perspectives. The specific perceptions result amongst others from the forming of the disciplinary researchers and of the actors' roles and contexts in the life-world, from the particular way researchers and actors are related to the problem, and from the specific social and natural conditions of the concrete situation. Each of the researchers and actors locates the problem in an alternative "world of relevance" (Limoges, 1993, 420). This diversity of perspectives must be taken into account when identifying and structuring the problem, when analysing it and when developing and testing means to deal with it.

To understand the diverse scientific and societal views of problems and engage in mutual learning and integration is a core challenge of TR (Becker and Jahn, 2006, 292-308). The first step in mutual learning and integration is to acknowledge the diversity of perspectives and to explore and clarify their differences (Giri, 2002; Loibl, 2005; Loibl, 2006; MacMynowski, 2007).

To access and explore the knowledge of researchers and actors in the life-world participatory social science methods of qualitative research, ethno-methodology and action research are useful. These qualitative methods complement quantitative research methods (Creswell, 1994; Gutscher et al., 1996). The analyst that uses such methods should be guided by the symmetry postulate "which enjoins us to seek the same kind of causes for 
Table 1. Possible combinations of forms of collaboration and means of integration (Pohl et al., 2008, 415).

\begin{tabular}{|c|c|c|c|}
\hline $\begin{array}{l}\text { Means } \\
\text { of integration }\end{array}$ & $\begin{array}{l}\text { Common } \\
\text { group } \\
\text { learning }\end{array}$ & $\begin{array}{c}\text { Deliberation } \\
\text { among } \\
\text { experts }\end{array}$ & $\begin{array}{l}\text { Integration } \\
\text { by a } \\
\text { subgroup } \\
\text { or } \\
\text { individual }\end{array}$ \\
\hline $\begin{array}{l}\text { Mutual understanding } \\
\text { (Everyday language, glossary...) }\end{array}$ & & & \\
\hline $\begin{array}{l}\text { Theoretical concept } \\
\text { (Transfer of concepts, mutual adaptation of concepts, bridge concepts...) }\end{array}$ & & & \\
\hline $\begin{array}{l}\text { Model } \\
\text { (Qualitative model, quantitative model, scenarios...) }\end{array}$ & & & \\
\hline $\begin{array}{l}\text { Product } \\
\text { (Technical device, database, regulation, exhibition...) }\end{array}$ & & & \\
\hline
\end{tabular}

both true and false, rational and irrational beliefs [... $]^{\prime \prime}$ (Bloor, 1991, 175). The purpose of the analysis is to depict the different collectives' perceptions and their particular rationale and not to qualify them. Ideally, such a symmetric positioning makes the analyst become a translator "helping each [perspective] to understand the stories of the others" (Yanow, 2000, 90). In doing so he/she aims to "open up new possibilities for reflexive and democratic engagement" (Irwin, 2001, 181) within the scientific communities and beyond.

Disciplines such as philosophy of science and science and technology studies (STS) contribute to the understanding of the diversity of perceptions. Disciplinary researchers or actors of the life-word think, talk and act differently, since they belong to different thought collectives (Fleck, 1986), social worlds (Star and Griesemer, 1989, 338), worlds of relevance (Limoges, 1993), paradigms (Kuhn, 1996), academic tribes and cultures (Becher, 1989; Galison, 1997) or policy cultures (Elzinga and Jamison, 1995; Elzinga, 1996). Such disciplinary or life-world communities share specific norms, knowledges, practices and discourses (Jasanoff and Wynne, 1998, 16-18; Miller, 2001, 485). The communities are heterogeneous in that the degree of affiliation with a community varies. Furthermore, the affiliation with a community is not exclusive. A researcher may at the same time be a member of more than one community.

Researchers and actors of the life-world have to ask themselves about the significance of their own and the other's perception of the problem. This requires relativizing one's own perspective and accepting other viewpoints as equally relevant. As Giri $(2002,105)$ states by quoting the Indian philosopher R. Sunder Rajan "each perspective or point of view is such only as a member of a community of points of view". Based on such a placement within the community of perspectives, the perspectives can begin to interact. In this second step of integration or synthesis, researchers' and actors' perceptions are interrelated and combined to develop knowledge and practices that help to solve the problem by promoting what is perceived to be the common good. We consider the methodological transdisciplinary challenge of integration to lie in how to specify and combine means of integration with forms of collaboration (Pohl and Hirsch Hadorn, 2007, 52-60; Pohl et al., 2008). Table 1 combines three forms of collaboration and four means of integration in a matrix that demonstrates twelve primary ways of integrating.

A research team may organise its collaboration as common group learning, deliberation among experts, or integration by a subgroup or individual (Rossini and Porter, 1979). Common group learning means that integration takes place as a learning process of the whole group. In deliberation among experts, each team member analyses the component of the problem that lies in her/his area of expertise. Integration takes place during one or more rounds of exchange among the experts. The notion of expert is not restricted to disciplinary researchers but also includes actors of the life-world. In the third form of collaboration a specific sub-group or individual undertakes the integration.

The four classes of "means" that we distinguish are mutual understanding, theoretical concepts, models and products. A ubiquitous complication encountered in the integration process is that of "not speaking the same language". Problems of mutual understanding arise when someone does not know the meaning of another community's terms or when someone is not aware of how a word changes meaning depending on the context. Such problems can be effectively addressed by making explicit what important terms mean, for example in a glossary. Another way of facilitating mutual understanding through effective communication is by deliberately using everyday language and avoiding scientific terms. This is what the Austrian research program Kulturlandschaftsforschung (KLF) proposed for its research projects (Nicolini, 2001). However, everyday language is not a universal panacea, as it is ambiguous and contextualised. A second means addresses integration by creating or 
restructuring the meaning of theoretical and conceptual terms. Such 'tools' comprise theoretical notions, which can be developed by (i) transferring concepts between disciplines, (ii) mutually adapting disciplinary concepts and their operationalisation to relate them to each other or (iii) creating new joint bridge concepts that merge disciplinary and/or life-world perspectives. A third means of integration is through models, be they hard models that integrate knowledge by correlating parameters from different disciplines, like in the world model (Meadows et al., 1972), or soft models that represent the different communities' perception and serve to depict a shared understanding or to facilitate mutual learning (Checkland, 1994). The fourth means of integration are products that a project aims at, like an exhibition or a city development plan.

The form of collaboration and the means of integration determine the structure and intensity of exchange between those involved. Intense exchange requires a deeper knowledge of one another's positions and a flexible attitude with regard to one's own position. If there is no debate about the contents of a product and if the primary purpose is to use the product to join the diverse interests of those involved, one may use the term "boundary object" (Star and Griesemer, 1989) to describe the approach to integration.

\section{Abstract and case-specific knowledge}

To find solutions that can become effective within a specific problem field and promote what is perceived to be the common good, TR must build a bridge between scientific knowledge produced under idealised conditions and the concrete situation in the life-world. Thus, TR is an interactive process between abstract and case-specific knowledge, which includes descriptive, normative and practice-oriented knowledge. This requirement is in line with the critique of the linear model as formulated by Stokes (1997), Gibbons and Nowotny and their colleagues (Gibbons et al., 1994; Nowotny et al., 2001) or Checkland (1985) and Schön (1983). Stokes $(1997,10)$ describes the rise of the linear model - "the belief that scientific advances are converted to practical use by a dynamic flow from science to technology" - as the leading paradigm after World War II. Innovation and information flow linearly from basic research, over applied research to development and production and operation. Schön $(1983,21)$ formulates the corresponding rationality of the practitioner as "instrumental problem solving made rigorous by the application of scientific theory and technique", what he calls technical rationality. In contrast to the linear model, critics consider the relationship between basic and applied science to be more complicated. Stokes $(1997,58-89)$ depicts both in a quadrant model of scientific research (ibid., 73). A research project can have a practical or a theoretical goal or both at once. Stokes calls the latter case in the quadrant model Pasteur's Quadrant, referring to Pasteur's work on microbiological processes. According to Checkland neither practice nor theory can be goals in and of themselves, as they mutually depend on each other: "Theory leads to practice; but practice is itself the source of the theory; neither is prime; the process generates itself" (Checkland, 1985, 757). There is a back and forth process between theory and practice. A recursive model replaces the linear model. Recursiveness means that the research process is shaped in such a way that theory and methods are repeatedly tested by applying them to practice, and that underlying assumptions can be modified if they are found to be inadequate. Such a recursive design is a pragmatic way to prevent a project from being stuck by uncertainty or the preliminary state of knowledge.

Disciplinary contributions to the issue of practical relevancy in a life-world situation are provided by operational or operations research (Argyris, 1976; Schön, 1983; Checkland, 1985), action research (Greenwood, 1999; Stringer, 2007) and policy sciences (Brewer, 1999; Clark, 2002). Operational research and action research also provide a number of participatory research methods like problem structuring methods (Mingers and Rosenhead, 2004), soft-systems thinking (Checkland, 1994) or the strategic choice approach (Friend and Hickling, 2005). These methods are generally used in a very pragmatic way, meaning that the contribution to problem solving in a concrete life-world situation is the main goal. HorlickJones and Rosenhead (Horlick-Jones and Rosenhead, 2007, 595) accordingly describe the problem structuring methods as a "methodological bricolage". The main dilemma of such an approach is perceived as the dilemma of "rigor or relevance": "Shall the practitioner stay on the high, hard ground where he can practice rigorously [...]? Or shall he descend to the swamp where he can engage in the most important and challenging problems if he is willing to forsake technical rigor?" (Schön, 1983, 42).

Researchers in transdisciplinary projects aim at knowledge for problem solving in the life-world that goes beyond counselling. For this purpose they also need to identify and systematize what can be learned from one case for other situations (Krohn, 2008). In contrast to disciplinary knowledge that generalizes findings on the basis of standardized conditions, TR aims at validating abstract models in concrete life-world situations. As a consequence, it is necessary to base knowledge transfer on real-word experiments, action-research or adaptive management.

Figure 2 illustrates the recursive application of bringing results to fruition in the form of a real-world experiment (Groß and Hoffmann-Riem, 2005; GroSS et al., 2005). In a real-world experiment the third phase of the transdisciplinary research process - bringing results 


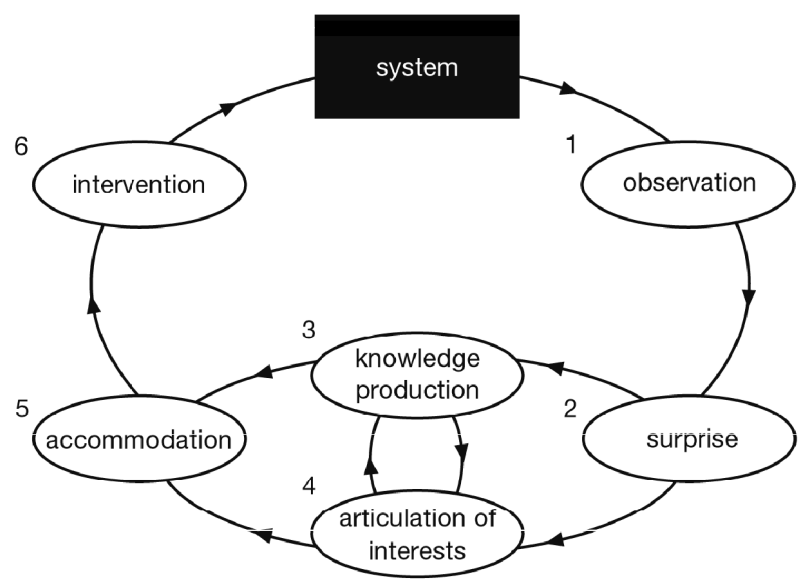

Fig. 2. Bringing results to fruition within a real-world experiment (Groß and Hoffmann-Riem, 2005, 275).

to fruition ("mise en valeur") - is not the final stage of implementation but a "experimental implementation" (van den Daele and Krohn, 1998) that enables learning processes. The effects of a project are observed, with a view to finding surprises (unexpected impacts). As a result, the assumptions, models and explanations developed in the project are revised in such a way that they can explain these surprises (increase of knowledge). New instances of bringing results to fruition are then planned and conducted etc. The reason for such recursive shaping is the requirement of taking into account the complexity of problems and the diversity of perceptions. In an experimental implementation, this complexity is articulated in unexpected side effects and in the way they are interpreted, in particular when such side effects run up against the actual objectives of the project. The recursive design and the real-world experiment are a means of reflection or getting reflective. It implies a critical assessment of the assumptions and models by which TR approaches a problem, as well as an observation of the expected and unexpected impacts of solutions proposed by TR, and the resulting adjustments that are made. Hubert and Bonnemaire (Hubert and Bonnemaire, 2000, 6), referring to Beck's reflective modernity (Beck, 1986), underline that this should not be understood as the task of science alone: "This approach to 'reflexive modernity' invites us to deal with these issues by learning to be reflexive together, that is the people who pose the problems, those who are implicated in the problems and those who help deal with them" (translation by A. Zimmermann).

\section{Promoting the common good}

TR develops knowledge to help solve, mitigate or prevent problems of the life-world. In doing so TR is embedded in a normative framework, which, instead of being implicitly assumed, has to be reflected on explicitly. This normative framework is provided by the concept of the common good, or the common interests which "are those that are widely shared within a community and demanded on behalf of the whole community" (Clark, 2002, 13). The common good as an ethical basis of democratic society and government builds also the core ethical idea of sustainable development (Hirsch Hadorn and Brun, 2007). The common good serves as a regulative idea for reflecting and deliberating controversial attitudes towards issues and plural values and norms at stake. As a socio-political ideal the concept of the common good is open to various interpretations. Neither particular researchers (e.g., ethicists) nor actors of the life-world (e.g., pastors, politicians) can give authority to a certain theory and definition of the common good or on how such a concept should be applied to a specific situation. Instead, how to specify the concept of the common good in view of the particular problem field is one of the research questions to be addressed in providing normative and practice-oriented knowledge. The main point is that a project team explicitly deals with the question of whether proposed solutions serve the common good - an important condition given the fact that actors from the private sector, public agencies, and civil society and disciplinary researchers may hold controversial positions.

Ethics and political philosophy contribute theories and methods for conceptual analysis (Plant, 1991). Political sciences, furthermore, provide participatory methods for deliberations such as hearings, advisory committees, panels and juries, mediation, negotiated rule making, round tables or consensus conferences (Renn et al., 1998), which can be useful as a means of knowledge production in the research process.

The specific transdisciplinary challenges for an explicit handling of the normative orientation arises in interrelating descriptive, normative and practice-oriented forms of knowledge. We distinguish these three forms of knowledge that are relevant in TR as follows: systems knowledge as knowledge of the current status; target knowledge as knowledge about a target status; and transformation knowledge as knowledge about how to make the transition from the current to the target status (ProClim, 1997). The same or similar distinctions are made by a number of scholars in the field of TR and sustainability science (Jantsch, 1972; Costanza et al., 1997; Deppert, 1998; Becker et al., 1999; Becker and Jahn, 2000; Brand, 2000; Burger and Kamber, 2003; Grunwald, 2004; Nölting et al., 2004; Wiek, 2007). Hubert et al. (2008) present illuminating examples of how the knowledge forms are interrelated, without, however, referring to this terminology. One of their examples is the idea to view different areas of a grazing land as courses of a menu. The menu helps to lead sheep 
Table 2. Problem structuring in TR in relation to the three forms of knowledge (based on Pohl and Hirsch Hadorn, 2007, 40).

\begin{tabular}{|l|l|l|}
\hline $\begin{array}{l}\text { Systems } \\
\text { knowledge }\end{array}$ & $\begin{array}{l}|c| \\
\text { Questions about the genesis and possible } \\
\text { development of a problem and about life-world } \\
\text { interpretations of a problem }\end{array}$ & $\begin{array}{l}\text { Questions for positioning } \\
\text { better practices does the research question refer? } \\
\text { To what technical, social, cultural, legal and other } \\
\text { possible means of acting does the research } \\
\text { question refer? }\end{array}$ \\
\hline $\begin{array}{l}\text { Target } \\
\text { knowledge }\end{array}$ & $\begin{array}{l}\text { Questions related to determining and explaining } \\
\text { the need for change, desired goals and better } \\
\text { practices }\end{array}$ & $\begin{array}{l}\text { To what understanding of the genesis and possible } \\
\text { development of a problem and life-world } \\
\text { interpretations of it does the research question } \\
\text { refer? } \\
\text { To what technical, social, cultural, legal and other } \\
\text { possible means of acting does the research } \\
\text { question refer? }\end{array}$ \\
\hline $\begin{array}{l}\text { Transformation } \\
\text { knowledge }\end{array}$ & $\begin{array}{l}\text { Questions about technical, social, cultural, legal } \\
\text { and other possible means of acting to transform } \\
\text { existing practices and introduce desired ones }\end{array}$ & $\begin{array}{l}\text { To what understanding of the genesis and possible } \\
\text { development of a problem and life-world } \\
\text { interpretations of it does the research question } \\
\text { refer? } \\
\text { To what kind of need for change, desired goals and } \\
\text { better practices does the research question refer? }\end{array}$ \\
\hline
\end{tabular}

through the menu/grazing land in such a way that two goals are reached at the same time: an efficient sheep growth and an ecological management of the grazing land. The menu leads to new research questions in livestock research: how does the chronology of plant intake influence sheep growth? This question is only meaningful under the specific target and the proposed transformation, i.e. the menu. That is, it depends on the assumed or intended target- and transformation knowledge.

Each form of knowledge corresponds with a specific kind of research question: systems knowledge addresses questions about the genesis and possible development of a problem, as well as about different interpretations of the problem and its causes; target knowledge addresses questions related to determining and explaining practiceoriented goals; and transformation knowledge addresses questions that concern the development, use and change of pragmatic means (technologies, institutions, laws, norms, etc.) (Pohl and Hirsch Hadorn, 2007, 36-40). Effective TR requires dealing with the three forms of knowledge as mutually dependent on each other. This means that research on one form of knowledge requires explicating the assumptions on the other two forms of knowledge. Table 2 summarizes for each form of knowledge the research question and the two questions that help position TR within the interdependent forms of knowledge.

Using the example of systems knowledge, Table 2 has to be read as follows: TR about systems knowledge deals with questions about the genesis and possible development of a problem and about interpretations of the problem and its causes. In order to produce systems knowledge that interrelates with target and transformation knowledge, two questions must be answered by the research team: To what kind of need for change, desired goals and better practices does the research question refer (target knowledge)? To what technical, social, cultural, legal and other possible means of acting does the research question refer (transformation knowledge)?

In the case of target knowledge, the assumptions about the genesis and possible development of a problem and specific options for transforming structures and practices have to be made explicit. For example, a comparative environmental assessment of two products is based on specific models of natural and economic processes, and suggests the distribution of a positively assessed product, assuming certain positive effects on social structures and practices. Recent TR projects generally do not deal with these questions explicitly, but make implicit assumptions. The positioning of TR within the three forms of knowledge should prevent such implicit assumptions from blocking the research process by making their consideration an explicit task of research.

\section{Conclusions: Self organized or facilitated competences for TR?}

So far we have proposed some reflections and a first more systematic account of TR. We expect by this to support researchers in better meeting the methodological challenges of TR. We provided some heuristic principles in designing and shaping the research process. They help address the complexity of an issue by relating the diversity of perspectives on a problem field and comparing abstract 
and case-specific knowledge in the search for means that help to solve, mitigate or prevent problems of the life-world. The question remains of how a hypothetical scholar who is interested in TR can get familiar with this methodology.

Gibbons, Nowotny and colleagues, in their essay on knowledge production in the context of application (Mode 2) argue for self-organized learning on the job, so to speak:

"Characteristically, Mode 2 research groups are less firmly insti-
tutionalised; people come together in temporary work teams and
networks, which dissolve when a problem is solved or redefined.
Members may then reassemble in different groups involving differ-
ent people, often in different loci, around different problems. The
experiences gathered in this process create a competence which
becomes highly valued and which is transferred to new contexts.
Though problems may be transient and groups short-lived, the
organisation and communication pattern persist as a matrix from
which further groups and networks, dedicated to different problems,
will be formed" (Gibbons et al., 1994, 6).

According to Gibbons, Nowotny and colleagues, the involved researchers and actors of the life-world meet for the project time and then dissolve. The experiences they make in collaboration with others in a context of application stay with the individual team members. None of them is responsible for elaborating and saving the lessons learned in a less personalised form. A subsequent project will have the same point of departure and will have to organize the process by itself, possibly (but not intentionally) by taking advantage of members who are already experienced in such projects.

Other scholars are mindful of the challenges in meeting the four requirements of transdisciplinary research and therefore draw attention to learning from and systematizing the experiences in TR. They call for new specialists that are experienced and trained in facilitating integration and implementation in research and that take responsibility for learning about the issues and building a college of peers to share experiences and advance the new discipline (Bammer, 2005). In the proposition for enhancing TR that concludes the "Handbook of Transdisciplinary Research" (Hirsch Hadorn et al., 2008), a strategy to combine disciplinary and transdisciplinary competences is proposed:

"The quality of transdisciplinary research is bound by sound
conceptions of integration and thus requires development of an
own form of specialisation. However, transdisciplinary research
is not meaningful without sound disciplinary contributions and
it has the potential to stimulate innovation in participating disci-
plines. Bringing this potential to fruition requires an emerging
college of peers able to bridge disciplinary and transdisciplinary
specialisation" (Wiesmann et al., 2008).

Coming back to the introductory question of forming students in TR, we ask again: is there a blueprint for a curriculum in TR and should the student become a specialist of TR by getting familiar with the methods? The answer is, yes and no. On the one hand, as in disciplinary research, TR cannot be learned as a toolbox. It is necessary to learn about TR from specific projects that serve as paradigms in understanding and structuring problems, which then can give rise to formalization. On the other hand, we tried to outline a body of knowledge that is of general relevance for doing TR and does not depend of the problem at stake. A curriculum would thus have to include disciplinary and transdisciplinary competences, whereas the body of transdisciplinary knowledge still needs some further clarifications.

\section{References}

Argyris, C., 1976. Single-loop and double-loop models in research on decision making, Administrative Science Quarterly, 21, 363-375.

Argyris, C., Schön, D.A., 1999. Die lernende Organisation : Grundlagen, Methoden, Praxis, Stuttgart, Klett-Cotta.

Bagamoyo College of Arts, Tanzania Theatre Centre, Mabala, R., Allen, K.B., 2002. Participatory action research on HIV/AIDS through a popular theatre approach in Tanzania, Evaluation and Program Planning, 25, 333-339.

Bammer, G., 2005. Integration and implementation sciences: Building a new specialization, Ecology and Society, 10, 2.

Becher, T., 1989. Academic Tribes and Territories: Intellectual Enquiry and the Cultures of Disciplines, Milton Keynes (England) / Bristol, PA (USA), Society for Research into Higher Education, Open University Press.

Beck, U., 1986. Risikogesellschaft : Auf dem Weg in eine andere Moderne, Frankfurt am Main, Suhrkamp Verlag.

Becker, E., Jahn, T., Stiess, E., 1999. Exploring Uncommon Ground: Sustainability and the Social Sciences, in Becker, E., Jahn, T. (Eds.), Sustainability and the Social Sciences, London, Zed Books Ltd, 1-22.

Becker, E., Jahn, T., 2000. Sozial-ökologische Transformationen Theoretische und methodische Probleme transdisziplinärer Nachhaltigkeitsforschung, in Brand, K.-W. (Ed.), Nachhaltige Entwicklung und Transdisziplinarität : Besonderheiten, Probleme und Erfordernisse der Nachhaltigkeitsforschung, Berlin, Analytica.

Becker, E., Jahn, T. (Eds.), 2006. Soziale Ökologie: Grundzüge einer Wissenschaft von den gesellschaftlichen Naturverhältnissen, Frankfurt/New York, Campus.

Bloor, D., 1991. Knowledge and Social Imaginary, Chicago/London, The University of Chicago Press.

Brand, K.-W., 2000. Nachhaltigkeitsforschung : Besonderheiten, Probleme und Erfordernisse eines neuen Forschungstypus, in Brand, K.-W. (Ed.), Nachhaltige Entwicklung und Transdisziplinarität: Besonderheiten, Probleme und Erfordernisse der Nachhaltigkeitsforschung, Berlin, Analytica, 9-28.

Brewer, G.D., 1999. The challenges of interdisciplinarity, Policy Sciences, 32, 4, 327-337.

Burger, P., Kamber, R., 2003. Cognitive Integration in Transdisciplinary Science: Knowledge as a Key Notion, Issues in Integrative Studies, 21, 43-73.

Checkland, P., 1985. From Optimizing to Learning: A Development of Systems Thinking for the 1990s, The Journal of the Operational Research Society, 36, 9, 757- 767. 
Checkland, P., 1994. Systems Thinking, Systems Practice, Chichester, Wiley.

Clark, T.W., 1999. Interdisciplinary problem solving: Next steps in the Greater Yellowstone Ecosystem, Policy Sciences, 32, 4, 393-414.

Clark, T.W., 2002. The Policy Process: A Practical Guide for Natural Resource Professionals, New Haven/London, Yale University Press.

Costanza, R., 2003. A vision of the future of science: reintegrating the study of humans and the rest of nature, Futures, 35, 6, 651-671.

Costanza, R., Cumberland, J., Daly, H., Goodland R., Norgaard, R., 1997. An Introduction to Ecological Economics, Boca Raton, St. Lucie Press.

Creswell, J.W., 1994. Research Design: Qualitative and Quantitative Approaches, Thousand Oaks, CA/London/New Delhi, Sage.

Daele, W. van den, Krohn, W., 1998. Experimental implementation as linking mechanism in the process of innovation, Research Policy, 27, 8, 853-868.

Defila, R., Di Giulio, A., 1999. Evaluating Transdisciplinary Research, Panorama, Special Edition, Swiss Priority Programme Environment, 1, 29.

Deppert, W., 1998. Problemlösen durch Interdisziplinarität, in Theobald, W. (Ed.), Integrative Umweltbewertung: Theorie und Beispiele aus der Praxis, Berlin, Springer, 35-64.

Elzinga, A., 1996. Shaping worldwide consensus The orchestration of global climate change research, in Elzinga, A., Landström, C. (Eds.), Internationalism and Science, Cambridge, Taylor Graham Publishing, 223-253.

Elzinga, A., Jamison, A., 1995. Changing policy agendas in science and technology, in Jasanoff, S., Markle, G.E., Petersen, J.C., Pinch, T.J. (Eds.), Handbook of Science and Technology Studies, Thousand Oaks, CA/London/New Delhi, Sage, 572597.

Fleck, L., 1986. The problem of epistemology, in Cohen, R.S., Schnelle, T. (Eds.), Cognition and Facts: Materials on Ludwik Fleck, Dordrecht/Boston/Lancaster/Tokyo, D. Reidel Publishing Company, 79-112.

Friend, J., Hickling, A., 2005. Planning under Pressure: The Strategic Choice Approach, Oxford, Elsevier.

Funtowicz, S.O., Ravetz, J.R., 1993. Science for the post- normal age, Futures, 25, 7, 739-755.

Galison, P., 1997. Image and Logic: A Material Culture of Microphysics, Chicago, The University of Chicago Press.

Gibbons, M., Limoges, C., Nowotny, H., Schwartzman, S., Scott, P., Trow, M., 1994. The New Production of Knowledge: The Dynamics of Science and Research in Contemporary Societies, Thousand Oaks, CA/London/New Delhi, Sage.

Giri, A.K., 2002. The calling of a creative transdisciplinarity, Futures, 34, 1, 103-115.

Greenwood, D.J., 1999. Action research: From Practice to Writing in an International Action Research Development Program, Amsterdam, Benjamins.

Groß, M., Hoffmann-Riem, H., 2005. Ecological restoration as a real-world experiment: Designing robust implementation strategies in an urban environment, Public Understanding of Science, 14, 269-284.

Groß, M., Hoffmann-Riem, H. Krohn, W., 2005. Realexperimente: Ökologische Gestaltungsprozesse in der Wissensgesellschaft, Bielefeld, transcript Verlag.

Grunwald, A., 1999. Ethische Grenzen der Technik? Reflexion zum Verhältnis von Ethik und Praxis, in Grunwald, A. and Saupe, S. (Eds.), Ethik in der Technikgestaltung - Praktische Relevanz und Legitimation, Berlin, Springer, 221-252.
Grunwald, A., 2004. Strategic knowledge for sustainable development. The need for reflexivity and learning at the interface between science and society, International Journal of Foresight and Innovation Policy, 1, 150-167.

Gutscher, H., Hirsch Hadorn, G., Werner, K., 1996. Vom Sinn der Methodenvielfalt in den Sozial- und Geisteswissenschaften, in Kaufmann-Hayoz, R., Di Giulio, A. (Eds.), Umweltproblem Mensch: Humanwisssenschaftliche Zugänge zu umweltverantwortlichem Handeln, Bern, Paul Haupt, 43- 78.

Häberli, R. Grossenbacher-Mansuy, W., 1998. Transdisziplinarität zwischen Förderung und Überforderung. Erkenntnisse aus dem SPP Umwelt, Gaia, 7, 3, 196-213.

Hirsch Hadorn, G., Brun, G., 2007. Ethische Probleme nachhaltiger Entwicklung, in Kaufmann[-Hayoz], R., Burger, P., Stoffel, M. (Ed.), Nachhaltigkeitsforschung: Perspektiven der Sozial- und Geisteswissenschaften, Bern, Schweizerische Akademie der Geistes / Sozialwissenschaften, 235-253.

Hirsch Hadorn, G., Hoffmann-Riem, H., Biber-Klemm, S., Grossenbacher-Mansuy, W., Joye, D., Pohl, C., Wiesmann, U., Zemp, E. (Eds.), 2008. Handbook of Transdisciplinary Research, Dordrecht, Springer.

Hollaender, K., Loibl, M.C., Wilts, A., 2008. Management, in Hirsch Hadorn, G., Hoffmann-Riem, H., Biber-Klemm, S., Grossenbacher-Mansuy, W., Joye, D., Pohl, C., Wiesmann, U., Zemp, E. (Eds.), Handbook of Transdisciplinary Research, Dordrecht, Springer, 383- 395.

Horlick-Jones, T., Rosenhead, J., 2007. The uses of observation: combining problem structuring methods and ethnography, Journal of the Operational Research Society, 58, 588-601.

Hubert, B., Bonnemaire, J., 2000. La construction des objets dans la recherche interdisciplinaire finalisée : de nouvelles exigences pour l'évaluation, Natures Sciences Sociétés, 8, 3, 5-19.

Hubert, B., Meuret, M., Bonnemaire, J., 2008. Shepherds, sheep and forest fires: A reconception of grazingland management, in Hirsch Hadorn, G., Hoffmann-Riem, H., Biber-Klemm, S., Grossenbacher-Mansuy, W., Joye, D., Pohl, C., Wiesmann, U. Zemp, E. (Eds.), Handbook of Transdisciplinary Research, Dordrecht, Springer, 103- 126.

Irwin, A., 2001. Sociology and the Environment, Cambridge (UK), Polity Press.

Jantsch, E., 1972. Towards interdisciplinarity and transdisciplinarity in education and innovation, in Apostel, L., et al., Interdisciplinarity: Problems of Teaching and Research in Universities, Paris, OECD, 97- 121.

Jasanoff, S. Wynne, B., 1998. Science and decisionmaking, in Rayner, S., Malone, E.L. (Eds.), Human Choice and Climate Change, Ohio, Battelle Press, 1-87.

Klein, J.T., 2008. Education, in Hirsch Hadorn, G., HoffmannRiem, H., Biber-Klemm, S., Grossenbacher- Mansuy, W., Joye, D., Pohl, C., Wiesmann, U., Zemp, E. (Eds.), Handbook of Transdisciplinary Research, Dordrecht, Springer, 399-410.

Krohn, W., 2008. Learning from case studies, in Hirsch Hadorn, G., Hoffmann-Riem, H., Biber-Klemm, S., GrossenbacherMansuy, W., Joye, D., Pohl, C., Wiesmann, U., Zemp, E. (Eds.), Handbook of Transdisciplinary Research, Dordrecht, Springer, 369-383.

Kueffer, C., Hirsch Hadorn, G. Bammer, G., van Kerkhoff, L., Pohl, C., 2007. Towards a publication culture in transdisciplinary research, Gaia, 16, 1, 22-26.

Kuhn, T.S., 1996. The Structure of Scientific Revolutions, Chicago, The University of Chicago Press. 
Lawrence, R.J., 2004. Housing and health: from interdisciplinary principles to transdisciplinary research and practice, Futures, 36, 4, 487-502.

Limoges, C., 1993. Expert knowledge and decision-making in controversy contexts, Public Understanding of Science, 2, 417-426.

Loibl, M.C., 2005. Spannung in Forschungsteams : Hintergründe und Methoden zum konstruktiven Abbau von Konflikten in inter- und transdisziplinären Projekten, Heidelberg, Verlag für Systemische Forschung im Carl-Auer Verlag.

Loibl, M.C., 2006. Integrating perspectives in the practice of transdisciplinary research, in Voß, J.-P., Bauknecht, D., Kemp, R. (Eds.), Reflexive Governance for Sustainable Development, Cheltenham, Edward Elgar, 294-309.

MacMynowski, D.P., 2007. Pausing at the brink of interdisciplinarity: Power and knowledge at the meeting of social and biophysical science, Ecology and Society, 12, 1.

Meadows, D.H., Meadows, D.L., Zahn, E., Milling, P., 1972. The Limits to Growth, New York, Universe Books.

Midgley, G., 2003. Systems Thinking, London, Sage.

Miller, C., 2001. Hybrid management: Boundary organizations, science policy, and environmental governance in the climate regime, Science, Technology E Human Values, 26, 4, 478-500.

Mingers, J., Rosenhead, J., 2004. Problem structuring methods in action, European Journal of Operational Research, 152, 530-554.

Mittelstraß, J., 1992. Auf dem Weg zur Transdisziplinarität, Gaia, $1,5,250$.

Mittelstraß, J., 1996. Enzyklopädie Philosophie und Wissenschaftstheorie, Stuttgart, Metzler.

Nicolini, M., 2001. Sprache-Wissenschaft-Wirklichkeit : Zum Sprachgebrauch in inter- und transdisziplinärer Forschung, Wien, Bundesministerium für Bildung, Wissenschaft und Kultur.

Nölting, B., Voß, J.-P., Hayn, D., 2004. Nachhaltigkeitsforschungjenseits von Disziplinierung und anything goes, Gaia, 13, 4, 254-261.

Nowotny, H., Scott, P., Gibbons, M., 2001. Re-Thinking Science: Knowledge and the Public in an Age of Uncertainty, Cambridge, Polity Press.

Plant, R., 1991. Modern Political Thought, Oxford, Blackwell.

Pohl, C., Hirsch Hadorn, G., 2007. Principles for Designing Transdisciplinary Research: Proposed by the Swiss Academies of Arts and Sciences, München, oekom Verlag.
Pohl, C., van Kerkhoff, L., Bammer, G., Hirsch Hadorn, G., 2008. Integration, in Hirsch Hadorn, G., Hoffmann-Riem, H., BiberKlemm, S., Grossenbacher-Mansuy, W., Joye, D., Pohl, C., Wiesmann, U., Zemp, E. (Eds.), Handbook of Transdisciplinary Research, Dordrecht, Springer, 411- 424.

ProClim, 1997. Research on Sustainability and Global Change: Visions in Science Policy by Swiss Researchers, Berne, CASS/SANW.

Renn, O., Kastenholz, H., Schild, P., Wilhelm, U. (Eds.), 1998. Abfallpolitik im kooperativen Diskurs, ETH Zürich, vdf.

Robinson, J., 2008. Being undisciplined: Transgression and intersections in academia and beyond, Futures, 40, 1, 70-86.

Rossini, F.A., Porter, A.L., 1979. Frameworks for integrating disciplinary research, Research Policy, 8, 70-79.

Schön, D.D., 1983. The Reflective Practitioner: How Professionals Think in Action, Aldershot, Hunts, Ashgate.

Star, S.L., Griesemer, J.R., 1989. Institutional ecology, 'translations' and boundary objects: Amateurs and professionals in Berkeley's Museum of Vertebrate Zoology, 1907-39, Social Studies of Science, 19, 387- 420.

Stokes, D.E., 1997. Pasteur's Quadrant: Basic Science and Technological Innovation, Washington, D.C., Brookings Institution Press.

Stringer, E.T., 2007. Action Research, Los Angeles, Sage Publications.

Truffer, B., Bratrich, C., Markard, J., Peter, A., Wüest, A., Wehrli, B., 2003. Green Hydropower: The contribution of aquatic science research to the promotion of sustainable electricity, Aquatic Sciences, 65, 99-110.

Wiek, A., 2007. Challenges of transdisciplinary research as interactive knowledge generation: Experiences from transdisciplinary case studies, Gaia, 16, 1, 52-57.

Wiesmann, U., Hirsch Hadorn, G., Hoffmann-Riem, H., BiberKlemm, S., Grossenbacher, W., Joye, D., Pohl, C., Zemp, E., 2008. Enhancing transdisciplinary research: A synthesis in fifteen propositions, in Hirsch Hadorn, G., HoffmannRiem, H., Biber-Klemm, S., Grossenbacher- Mansuy, W., Joye, D., Pohl, C., Wiesmann, U., Zemp, E. (Eds.), Handbook of Transdisciplinary Research, Dordrecht, Springer, 433-441.

Wynne, B., 1992. Misunderstood misunderstandings: Social identities and public uptake of science, Public Understanding of Science, 1, 281-304.

Yanow, D., 2000. Conducting Interpretative Policy Analysis, Thousand Oaks, CA/London/New Delhi, Sage.

Received 8 January 2008. Accepted 6 March 2008. 